\title{
Eventyrets tid, historiens rum
}

\section{Trediveårskrigens dynamik i Den eventyrlige Simplicissimus}

I bog to, kapitel 20 af Hans Jakob Christoffel von Grimmelshausens roman ${ }^{\mathrm{I}}$ Den eventyrlige Simplicissimus (1668 [1669]) befinder helten Simplicius sig i en soldaterlejr uden for Magdeburg, hvor han i selskab med sin hovmester betragter kompagniets store spilleplads. Hovmesteren forklarer i gudfrygtige vendinger, hvordan hasardspillet er den værste beskæftigelse, man kan give sig i kast med, eftersom den leder alle - vindere som tabere - i fordærv:

64 Man siger, at ethvert kast er djævelens, og på samme måde, sagde han, måtte det stå mig klart, at med hver terning, der af spillerens hånd kastedes på kappen eller bordet, fulgte der en lille djævel, som styrede terningen og gav den netop det antal øjne, som hans principals interesser krævede. (Grimmelshausen, II, 126)

Moralprædikenen er tænkt som en advarsel til den endnu uskyldige Simplicius, men som læser af passagen fristes man til at anskue hele scenen som en allegori over romanens struktur og den megen tumult, hovedpersonen allerede har og endnu mangler at gennemleve. De mange op- og nedture synes at være underlagt bestemmelser, der ligger uden for subjektets handlingshorisont for i stedet at tilhøre terningespillets evindelige forandring, som dog kontrolleres mere af den indgribende skæbne end af tilfældets luner. Allegorien bliver endnu tydeligere, da hovmesteren efterfølgende erklærer, at han agter at skrive en bog om fænomenet og udmale det "på en sådan måde, at de, der bare læser en sådan bog een gang, vil få en så voldsom afsky for spillet, som om de allerede havde drukket somælk" (s. 126). I stedet er det Simplicius, der ender med at nedskrive sit liv og levned i håb om, at andre kan lære af hans fortælling.

Uddraget ovenfor indeholder en række forhandlinger: mellem kontingens og fatalisme, mellem fortæller og karakter, mellem underholdning og opbyggelighed. Samtidig knyttes der an til spørgsmålet om romanens eventyrlige fundering og hele komposition. Da det bogstavelig talt vrimler med hekse og djævleskikkelser på 
Simplicius' færd gennem et af Trediveårskrigen hærget Europa, optræder hvad der ligner realhistoriske krigsscener ${ }^{2}$ og overnaturlige elementer side om side. Denne umiddelbare diskrepans har dog ikke kunne ændre på, at Grimmelshausens værker ofte er blevet læst i lyset af krigen, som startede i Prag i 1618 og sluttede med Den Westfalske Fred i 1648 og sågar har indtaget en position som vidnesbyrd for de lidelser, den hovedsageligt tyske befolkning måtte udstå (Mannack 2002, 702).

Anvendeligheden af Grimmelshausens skrifter som kilder til denne katastrofale begivenhed har gennem tiden været det store omdrejningspunkt i receptionshistorien. Grundene hertil er mange, men den autobiografiske udsigelsesposition har ofte været det væsentligste argument for at læse værket som en historisk kilde (Meid 1984, 121-123). Thomas Mann og Günther Grass har understreget bogens historiske erkendelsesrigdomme. Sidstnævnte beundrede især Simplicissimus' evne til at formidle netop de udsattes faktiske situation under krigen. ${ }^{3}$ I nyere tid har man dog nedtonet romanens realistiske status markant og taget afstand fra dens brugbarhed som troværdig historisk kilde (se især Alewyn 1932 og Aylett 1982). Herhjemme har Michael Harbsmeier givet udtryk for lignende synspunkter ved i sin vurdering af Simplicissimus' sandhedsværdi at sige, "at der hverken er tale om selvbiografi eller et forsøg på en realistisk beskrivelse af virkelige hændelser, men derimod om en litterær tolkning og bearbejdelse af en virkelighed og nogle erfaringer, som vi burde bruge andre kilder til at belyse" (Harbsmeier 2012, 20). At problemerne om realisme, autenticitet og sandhed i visse henseender er forkert stillet op, synes allerede at have foresvævet Volker Meid, når han i sin bog fra 1984 om Grimmelshausens epoke og værk påstår, at realismediskussionen på rigid vis har forsøgt at isolere henholdsvis de overnaturlige og umiddelbart virkelighedstro kapitler i adskilte læsninger, som på hver deres måde negligerer værkets kompleksitet (Meid 1984, 122).

Jeg vil i det følgende forsøge at tilgå spørgsmålet om Trediveårskrigens tilstedeværelse og funktion i Den eventyrlige Simplicissimus ud fra en undersøgelse af romanens konfiguration af tid og rum, hvilket i samme ombæring vil fordre nye perspektiver på samspillet mellem form og indhold, der, så vidt jeg ved, ikke forefindes andetsteds i forskningslitteraturen. Krigen betragtes dermed først og fremmest som et rent litterært fænomen, og ekstern historisk kontekstualisering vil kun inddrages i de tilfælde, hvor det motiveres af værket selv. ${ }^{4}$

Det betyder også, at målet for undersøgelsen ikke er en faktabaseret krydslæsning mellem værk og virkelighed, med udgangspunkt i, hvor troværdig en fremstilling af krigen, Grimmelshausen formår at give. Derimod vil jeg hævde, at romanens historiske signifikans skal findes i dens litterære iscenesættelse af dynamikken mellem Simplicius' skiftende identiteter og de ligeledes skiftende rum, han optræder i. Disse dynamiske forvandlinger står i et kontrastfuldt forhold til den statiske tidsopfattelse, som er indeholdt i værkets eventyrlige komposition. Artiklen vil først beskæftige sig med værkets tid begyndende med netop kompositionen, for derefter at se nærmere på romanens udsigelsesposition. Her vil det blive tydeligt, at Grimmelshausens prioritering af den retrospektive selvfortælling, eller det vi med Stanzel kan kalde værkets kvasi-autobiografiske jeg-gestalt (Stanzel 1972, 32), blotlægger forskellige niveauer af tid og samtidig muliggør en 
drøftelse af karakterudviklingens relation til de rum, jeg i det følgende vil påstå er essentielt historiske.

\section{Eventyrlig komposition}

Det er en udbredt anskuelse, at Grimmelshausens bog skal betragtes som tysk litteraturs tidligste eksempel og højdepunkt inden for den pikareske romangenre (Meid 1974, 76-78). Simplicissimus lægger sig i forlængelse af tidligere eksempler på genren som de spanske Lazarillo de la Tormes (1554) og Guzmán de Alfarache (1599-1604) ved på den ene side at etablere en autobiografisk udsigelsesposition, hvor en tilbageskuende fortæller beretter om sit forunderlige liv, og på den anden side via helten eller pikaroen at fremstille et plot, der præsenterer læseren for et bredspektret tværsnit ned igennem samfundets sociale hierarkier. Som en lavlitterær kommentar til den idealiserende ridderroman søger skælmeromanens handling at portrættere konkrete og velkendte steders topografi, ofte med udgangspunkt i underklassens levevis. På det horisontale plan rejser Simplicius gennem krigens geografiske rum, som foruden de tysktalende områder blandt andet tæller Frankrig og Schweiz. På det vertikale plan indføres læseren derimod i krigens sociale rum, og Simplicius når at fungere som eneboer, nar, jægeren fra Soest, pilgrim, kvaksalver og meget andet. Pikaroens fleksibilitet på disse to akser gør det dermed muligt at konstruere et mangfoldigt katalog over Trediveårskrigens sociogeografiske fremtrædelsesformer. Det er naturligvis lidet realistisk, at hovedpersonen som en fattig bondesøn skulle kunne nå at se og opleve alt dette, og mængden af tilfældigheder og velplacerede hjælpere og modstandere er betydelig. Det er ikke for ingenting den eventyrlige Simplicissimus, vi skal høre om, og navnlig på det strukturelle niveau bliver den genrehistoriske arv fra den vestlige eventyrtradition synlig. ${ }^{5}$ I en diskussion af Trediveårskrigens tilstedeværelse i tekstuniverset og af de tidskonfigurationer, som ligger bag, er det nødvendigt at overveje, på hvilke måder denne eventyrtradition kommer til syne. Jeg vil her påstå, at de eventyrlige elementer i Simplicissimus mindre har at gøre med de overnaturlige scener, der på indholdssiden omhandler heksesabbatter, rejser til jordens indre eller talende lokumspapir, og mere med den form, hvormed handlingens episoder sættes i spil.

Et klassisk strukturelement, der er kendetegnende for eventyrgenren, er plottets episodiske karakter (Propp 1973, 92). Simplicissimus mimer denne form ved at lade de enkelte scener lukke sig om sig selv i en sådan grad, at relationerne til de forudgående og efterfølgende episoder ofte er minimal. I stedet for logiske sammenhænge består den narrative struktur af pludselige brud og diskontinuerlige skift (Mohr 2011, 230). Eksempelvis er Simplicius i bog 2, kap. 14 endelig begyndt at vinde guvernørens gunst i den fæstning, han befinder sig i, da han af uransagelige årsager pludselig befinder sig uden for bymurene og ligeså pludseligt bliver taget til fange af en gruppe fouragerende kroater (II, 109-111). Fra det ene sekund til det andet bliver både tid og sted vendt på hovedet i det barokke lykkehjul. ${ }^{6}$ Senere i romanen lyder det lamenterende fra Simplicius: "Oh, hastige ulyksalige forandring!" (IV, 94). Her har han netop mistet både formue, udseende og chancen for at blive delingsfører på grund af de skoldkopper, han erhverver sig på en rejse fra Paris til Køln. Fra at være 
den smukkeste troubadour i Frankrig og kongens ven, ligger han nu for døden og må senere tigge sig til Strasbourg, hvor han er så heldig at møde sin gamle ven Herzbruder, hvorved glæden igen vender tilbage for en stund. Omvæltningerne synes så radikale, at man mistænker den autobiografiske fortæller for at være den førnævnte principal, der bestemmer udfaldet af terningernes lykkespil. Den fortællende instans træder i forgrunden, eftersom de mange (på overfladen tilfældige) sceneskift ofte har en tematisk, didaktisk eller plotfremdrivende motivering. Fortælleren italesætter selv den eventyrlige komposition i bog to, kap. 18, efter at Simplicius i det forudgående afsnit har været vidne til en højest mærkværdig heksesabbat på Bloksbjerg:

64 Eftersom der findes mennesker, derunder også fornemme og lærde folk, der ikke tror på hexe eller troldpak, og end mindre på, at sligt kan fare frem og tilbage i luften, tvivler jeg ikke på, at mange vil sige: at her maler Simplex nok med den brede pensel. Disse folk vil jeg nu ikke strides med, for da det i vor tid ingen kunst er at lyve, men løgnen er blevet det allermest almindelige håndværk, så kan jeg ikke nægte, at jeg er kyndig udi samme. [...] thi jeg er ligeglad med, om man tror mig eller ej. Og den, som ikke vil tro mig, kan jo prøve på at finde nogen anden måde, på hvilken jeg kunne komme så hurtigt fra stiftet Hirschfeld eller Fulda (jeg véd nemlig selv ikke, hvor langt jeg var strejfet omkring i skovene) til ærkestiftet Magdeburg. (II, 118-120)

Om vi tror ham eller ej, kan vi under alle omstændigheder konstatere, at handlingen med ét er rykket cirka $300 \mathrm{~km}$ i nordøstlig retning. Som små øer placeres de enestående episoder i teksten, og det bliver tydeligt, at der i deres indbyrdes sammenhæng i højere grad er et nebeneinander end et nacheinander. Rejsen gennem Trediveårskrigens sociogeografiske rum fremstilles dermed kompositorisk ud fra synkrone nedslag, og det er svært at få øje på den kausale linearitet og successive fremdrift, der spiller så stor en rolle for eksempelvis dannelsesromanen i begyndelsen af 1800-tallet.

Den bestandige med- og modgang og genkomsten af visse karakterer er alt sammen med til at bestyrke romanens cirkulære opbygning, hvilket de mange direkte og indirekte gentagelser også bærer vidne om. Det er ligeledes bemærkelsesværdigt, at helten i den fortalte handling starter og slutter bogen i en fra verden isoleret tilstand. Eventyrlige forvandlinger er ikke blot forbeholdt det formelle niveau, men har også en afgørende betydning i den dramatiske handling, hvilket ses i Simplicius' leg med masker og anden forklædning. Draperet som djævel forskrækker han først nogle dragoner (II, 113-115) og senere en landsbypræst (II, 152-158), førend han selv jages en skræk i livet af en sort dreng, han tager for at være Lucifer selv (III, 25). Da Simplicius som jægeren fra Soest er på sin militære karrieres højdepunkt, møder han en mand, som udgiver sig for at være guden Jupiter. Denne naragtige skikkelse afspejler på komisk vis de tidligere scener i romanen, hvor Simplicius selv måtte optræde som hofnar (III, 11-21).

"Man ser, at ene ubestandighed bestandig er - i sorg og glæde, krig og fred" (VI, 77). Med denne epigraf indledes sjette og sidste bog, og udsagnet kan med fordel tolkes som værkets underliggende princip. Eventyrkompositionen, cirkulariteten og de evigt spejlende gentagelser gør, at romanens tidsgestalt forekommer 
ahistorisk. En tidsdimension som denne står i et umiddelbart modsætningsforhold til den historiske spatialitet, jeg fremhævede ovenfor, og spørgsmålet er, hvilke mulige fremstillinger af Trediveårskrigen dette forhold tillader.

\section{Tid og (selv)fortælling}

Modsætningerne lader sig bedst beskrive igennem romanens helt. Med den fortællende Simplicius som kompositorisk maestro og den oplevende Simplicius som det skæringspunkt i koordinatsystemet, hvorigennem krigens rumlige livsverden udstilles, er det værd at se nærmere på de to niveauers indbyrdes forhold. Forholdet er ofte blevet beskrevet ud fra et kristent, moralsk værdisæt, hvor hændelserne, som de erfares af romanens selvsagt simple hovedperson, altid tilskrives en fortolkende merbetydning af den fortællende og af bagklogskab oplyste Simplicius (se især Maroszová 2015, 114-117). Dette syn på fortællerelationerne har foranlediget ikke så få studier, hvori Simplicissimus sammenlignes med bekendelseslitteratur a la Augustin (f.eks. Konopatzki 1965). Når den didaktiske frelseshistorie er blevet tolket som den underliggende grundfortælling, skal årsagen blandt andet findes i Simplicius' verdensforsagende eremittilværelse på en $\emptyset$ de $\emptyset$ ved slutningen af sjette og sidste bog. Der er dog god grund til at opponere imod læsningen af sjette bogs eneboerliv som en endelig kristen konversion og definitiv afslutning på Simplicius' liv. Helten gennemgår et væld af pseudokonversioner i løbet af romanen, for efterfølgende at falde tilbage til ugudelige leveveje (Heckman 1969, 880-882; Meid 1984, 138), og læseren har ikke stor tiltro til, at netop denne omvendelse skulle være endelig. ${ }^{7}$ Simplicissimus låner utvivlsomt fra de foreliggende omvendelsesskabeloner, men problemet med en entydig religiøs læsning af romanen er, foruden de direkte modsætninger, teksten selv indeholder på dette punkt, ${ }^{8}$ at både tiden og krigen ofte reduceres til udelukkende at være allegoriske størrelser. Ved at se bort fra fortællingen som en hellig bekendelse og tiden som mytologiseret, åbnes et alternativt blik på de tidslige brudflader i forholdet mellem fortæller og karakter.

I en række nylige udgivelser har Lukas Werner åbnet et sådant blik ved at se bort fra frelsertemaet og i stedet behandlet relationen mellem tid og fortælling i Simplicissimus med afsæt i nogle af de teoretiske og metodiske nybrud inden for især tysk litteraturvidenskab, som går under samlebetegnelsen "historisk narratologi". ${ }^{9}$ Nærværende artikels fokus er langt hen ad vejen på linje med Werners studier, idet han mener, at udgangspunktet for en historisering af tiden som fortælleteoretisk kategori skal findes inden for tekstens egne rammer:

4 Følgende udsagn er baseret på overbevisningen om, at et relationelt tidsbegreb - hvad angår historisering - sætter den fortællende teksts komposition og litteraritet i forgrunden, frem for en historisering af tid der søger at indbefatte tekstens sociohistoriske, diskursive eller andre ikke-litterære sammenhænge. (Werner 2018, 37, min oversættelse) ) $^{\text {Io }}$

I tilfældet Simplicissimus kommenterer han de konkrete tidsmarkører, der findes i teksten. Et bemærkelsesværdigt karakteristikum ved romanen er, at datoer er så godt som udeladt i handlingen, hvilket, kan man forestille sig, har frustreret mange 
sammenlignende læsninger af Trediveårskrigen og Grimmelshausens værk. Tidsfornemmelsen fremstilles i stedet ud fra et skel mellem dage, uger, måneder og år foruden årstiderne. Da helten tages til fange af en svensk oberst i Soest hedder det eksempelvis: "Samme nat overvejede jeg, hvordan jeg skulle forme mit liv i fremtiden, og besluttede mig derfor at forblive de sex måneder, hvor jeg var, og altså tilbringe vinteren, der nu stod for døren, i ro" (III, 50). I scenen med de førnævnte skoldkopper hedder det også: "For fire uger siden var jeg en karl, der bevægede fyrsterne til forundring, henrykkede kvinderne og forekom folk at være et mesterstykke af naturen, ja en engel, men nu var jeg så uværdig, at hundene pissede på mig." (IV, 94). Vi ved, at Simplicius' rejse går tværs igennem den europæiske krig, men på grund af den manglende datering har læseren kun de specifikke steder og benævnelsen af historiske personligheder at ty til i et fors $\varnothing \mathrm{g}$ på at rekonstruere en historisk kronologi. Krigen bryder bogstavelig talt ind i den unge og enfoldige Simplicius' liv i bogens åbning, da en gruppe soldater hærger den fædrene gård i Spessert. Men det er først langt senere (i en sammenlignende læsning af bog 1, kap. 22 \& bog 5, kap. 8), at en realhistorisk tid træder ind i værket ved at placere protagonistens fødsel i umiddelbar forlængelse af slaget ved Höchst (juni 1622). Af lignende tilfælde kan nævnes slaget ved Wittstock (oktober 1636), som Simplicius selv deltager i, og slaget ved Wittenweiher (august 1638), hvor vennen Herzbruder taber under Johann von Götzens ledelse.

Tidspunktet er altid indlejret i en bestemt begivenhed eller relateret til en historisk karakter, hvilket betyder, at kalendertidens abstrakte dimension af dage, måneder og år først via de nævnte begivenheders konkretion tilskrives en historisk tyngde og som sådan bliver synlig i romanens fremstilling (Werner 2015, 92). Selv i de tilfælde, hvor selvfortællingen er eksistentielt motiveret og omhandler det fortalte jegs sindsstemninger, er han ikke centrum for en selvstændig tidsopfattelse (s. 93). Heltens tidsopfattelse er derimod objektiv og, som anført i eksemplerne ovenfor, knyttet til det naturligt/cykliske. Hvis en egentlig subjektiv tidsfornemmelse er fraværende hos karakteren Simplicius, har det som en af sine konsekvenser, at tiden altid vil være vævet sammen med fænomener, som ligger uden for individet $\mathrm{i}$ tekstuniverset.

Med Werner bliver tiden et problem, som skal opsøges på det formale plan, idet al subjektiv tidsforståelse, der måtte findes i romanen, udspringer fra fortællerens position. I lyset af de nyere og især poststrukturalistiske forbehold over for det selvudgrundende og stabile subjekt fristes man til i Werners pointe at se et udtryk for en mere generel problemstilling indeholdt i selvrepræsentationen. For at opnå genkendelse og forståelse må selvfremstillingen moduleres over en række fælles normer, hvilket har den effekt, at flere vektorer af tid bryder ind i den singulære historie og udfordrer, hvad der traditionelt er blevet opfattet som en isoleret og personlig fortælling (se f.eks. Butler 2001). Hvis Simplicius i romanen er en karakter tømt for selvstændig tid, bør en analyse i stedet have blik for, hvilke andre tidsdimensioner i tekstuniverset der, foruden den rent private, løber igennem ham. I Simplicissimus ser vi, hvordan den tilbageskuende jeg-fortæller ikke blot indlejrer sin egen tidsopfattelse i sit tidligere selvs dvs. romanens helt, men også hvordan omgivelsernes tidsspecifikke historicitet i form af steder og personligheder trænger ind i selvfortællingen. 


\section{Transfiguratio Simplicissimus}

Konsekvenserne af ovenstående er for det første, at det forekommer problematisk at tale om karakteren Simplicius som et individ, der besidder en fast, immanent identitet. For det andet giver den manglende indre tidsdimension et indtryk af helten som overfladisk eller offentlig, hvilket samtidig åbner for et relationelt perspektiv på romanens konfiguration af identitet og rum. Som allerede anført spiller masker, forklædninger og en generel skuespilmetaforik en stor rolle i handlingen. De karnevalistiske episoder er med til at undergrave ideen om fast identitet yderligere, men en distinkt egenskab ved Simplicius, som adskiller ham fra åndsfæller som Lazarillo, Guzman og Don Quijote, er hans evne til ikke bare at optræde, som om han er en anden, men rent faktisk at være en dragon, en troubadour eller en pilgrim. Når Grimmelshausens roman på så bemærkelsesværdig vis kan fremmane et detaljeret portræt af krigens persongalleri, er det ikke (kun) via protagonistens rejse mod erkendelse gennem talrige møder med datidens befolkningsgrupper. Derimod præsenteres Trediveårskrigens rum, dets mangfoldige skikkelser og deres indbyrdes relationer for læseren i kraft af de samfundspositioner, Simplicius helt konkret inkarnerer. De mange forvandlinger er igen med til at understrege en mangel på indre substans i Simplicius' person. Nyere forskning har gjort ret i at nedtone tidligere opfattelser af værket, hvori dets karakter af dannelsesroman blev set i lyset af et genreparadigme fra Goethetiden (Meid 1984, 137-138). Simplicissimus ligger langt fra den kontinuerlige og organiske udvikling, som kendetegner 1800-tallets dannelseslitteratur. Det ville ligeledes være fejlagtigt at overføre den introspektive dybdepsykologi, vi kender fra det romantiske subjekt eller den moderne litteraturs karakterer til Simplicius-gestalten. Den fraværende indre tidsfornemmelse er, som Werner pointerede, et udtryk for samme mangel. Ifølge Meid giver det mere mening at omtale helten som en type eller figur, end som et individ (s. 138).

I denne sammenhæng bliver det derfor afgørende at se nærmere på, hvor og hvordan disse forvandlinger finder sted, og hvilken forbindelse der er til de rum, Simplicius interagerer med. Det indbyrdes forhold mellem krig, rum og identitet beskrives af Ansgar Cordie på følgende måde:

46 Trediveårskrigens Centraleuropa er ikke et tilfældigt sujet for en i genre forklædt allegori. Den former snarere den verden, som helten tilegner sig, og hører dermed til romanens substans. Handlingens rumlige og tidslige ramme er ikke en teaterkulisse for et tidsløst theatrum mundi, men det objektive handlingsfelt, hvori heltens subjektivitet, hans umiskendelige biografi, overhovedet først konstitueres. Omvendt er det først gennem heltens bevægelse, at denne objektive verden kommer til syne. (Cordie 2001, 350, min oversættelse) ${ }^{\text {II }}$

For Cordie er rummet ikke kun et bagtæppe for handlingen, men en indvirkende, symbolsk aktør. Endvidere kan vi sige, at rummet, foruden at være en aktiv medspiller i romanen, har en direkte indflydelse på udformningen af hovedpersonens væren. Men samtidig - og det er her, en historisk udvikling efter min mening bliver synlig - påvirker Simplicius' tilstedeværelse også de forskellige rums udformninger. ${ }^{\mathrm{I} 2}$ Den gensidige konstituering af karakter og rum giver Trediveårskrigen en 
plotskabende og karakterudviklende agens. Indeholdt heri er også argumentet om, at krigens tilstedeværelse mindre skal findes i de få og perifere historiske mark $\varnothing$ rer, som blot tjener til at ramme handlingen ind, og mere i det sociogeografiske landskab, der med sin indgriben i heltens fremtoning avler romanens dynamik. I en afsluttende analyse af en af bogens absolutte nøglescener vil jeg forsøge at påvise, hvordan Simplicius' indflydelse på romanens rum indvarsler en række forandringer, jeg vil tilskrive en historisk betydning.

Inden da er det dog værd at uddybe, hvorfor jeg artiklen igennem har tillagt begreberne dynamik og forvandling en udpræget historisk funktion i Grimmelshausens værk. Tidligt i romanen har Simplicius en drøm, der populært går under betegnelsen "stændertræs-allegorien":

6 Da syntes jeg ligesom i en drøm at se, at alle træer omkring min bolig forandredes og antog et helt andet udseende. I hver top sad en rytter, og alle grene prydedes i stedet for blade af allehånde karle [...] Dette var morsomt at se på, fordi det hele bredte sig så fint og ordentligt ud efter rangforordningen. Rødderne bestod imidlertid af ubetydelige folk såsom håndværkere og daglejere, mange bønder og lignende, der ikke desto mindre gav træets dets kraft og ny styrke, når det fra tid til anden mistede denne. (I, 39)

Senere i visionen forenes træerne under krigsguden Mars, der fra toppen har overblik over krigssamfundets forskellige lagdelinger. Over de arbejdende folk kommer den menige soldaterstand og efter dem de erfarne krigskarle, som med held og flid har overlevet krigens strabadser. Men over disse igen:

6 havde træstammen en afsats eller en slags skillerum, som var et glat stykke, uden grene, smurt med misundelsens forunderlige materialer og skinsygens sælsomme sæber, så at altså ingen mand, medmindre han var af adelen, kunne stige op, hverken ved mandighed, dygtighed eller klogskab, uanset hvor godt han kunne klatre. (I, 41)

At allegorien er struktureret som et træ, er ingen tilfældighed. Krigens hierarkier er i drømmesynet fremstillet som en social vertikal, der på raffineret vis afspejler de klasseskel, som samfundet var inddelt i på Grimmelshausens tid. Selv under tumultariske og kaotiske krigstilstande bevares adelens privilegier, hvilket gør menigmands mulighed for avancement så godt som umuligt. Træet kan i Simplicius' drøm tolkes som en konkret manifestation af de traditionelle standsforhold, men samtidig ledes tankerne hen på stamtræet, der, som baggrund for adelens magtpositioner i freds- såvel som krigstid, besad en vigtig symbolsk betydning i 1600-tallet. Interessant i dette tilfælde er ikke kun allegoriens betydning, men også dens placering i romanen. Simplicius er på det tidspunkt, hvor drømmen indtræffer, endnu uden viden om, hvad der foregår i verden, hvorfor han umuligt har kunne producere mening af synet. I stedet er der igen tale om fortællerens manipulation af episodernes rækkefølge i plottet (se også Heckman 1969). Konsekvensen af denne kompositoriske prioritering er, at Simplicius' førnævnte rejse horisontalt såvel som vertikalt gennem krigens steder og hierarkier kommer til at stå i en skarp kontrast til den stasis, stændertræet repræsenterer. For at understrege sin sociale opstigning 
anskaffer Simplicius sig i sine velmagtsdage ligefrem et adeligt våbenskjold (jf. III, 34). Minimum to fortolkningsmuligheder træder her frem: Enten er hele bogen i dens skildring af heltens sociale mobilitet ét stort dementi af den indledende allegori om stændertræet. Eller også skal Simplicius-figuren forstås som et heterologt fænomen, der falder uden for samfundets normaltilstande. Jeg vil forfølge sidstnævnte mulighed ved at se nærmere på heltens ankomst til fæstningen Hanau og de mekanismer, hans tilstedeværelse initierer, dvs. bog et, kap. 19 til bog to, kap. 14 .

\section{Historiens rum: Simplicius i Hanau}

En spekulativ læsning af karakteren Simplicius som et fra verden adskilt fænomen må tage sit udgangspunkt i metafysikken forstået som en disciplin, der blandt andet beskæftiger sig med de excesser, som produceres af en rationel civilisation (Nancy 2009). Excesserne er på én gang konstituerende og faretruende for et fornuftsregimes forudsætning og berettigelse. Sådanne metafysiske udskillelser kan optræde under navne som: "Gud", "den anden”, "væren”, "det sublime”. I et forsøg på at opretholde og reproducere den logik, der er dets grundlag, vil et samfund forsøge at ekskludere alt ikke-identificerbart, som falder uden for dets rationale eller dets principium reddendae rationis, som det hedder hos samtidsfilosoffen Leibniz. Excessen muliggør en grænsedragning mellem det, som findes inden for det rationelle fællesskab og det, som findes uden for - i vores tilfælde det interne mikrokosmos i Hanau og de barbariske tilstande, der hersker uden for bymurene. Bemærk, hvordan beskrivelsen lyder, da Simplicius først ankommer til fæstningen: “Jeg blev altså ført ind i staden, og alle kom løbende til, ganske som om et havuhyre var udstillet til beskuelse. Og ligesom alle ville se mig og betragte min forunderlige fremtoning nøjere, tog også enhver mig som noget andet end Næsten” (I, 48). Episoden er heltens første møde med verden siden angrebet på fædregården og tilværelsen som skoveremit, hvorfor samfundet i Hanau er lige så fremmed for ham, som han er fremmed for det. Aristoteles skriver i sin statslære, at mennesket fra naturens side er et politisk væsen, som hører til i polis. Uden polis er man enten over eller ved siden af menneskeheden - man er stamme-, lov- og hjerteløs (Aristoteles 2012, 35). Aristoteles' formulering trækker en skarp skillelinje imellem civilisation-ens kendte domæne og barbariets ukendte. Simplicius er fremmed i en grad, hvor han ikke bare er uigenkendelig i forhold til fæstningens indre struktur; den hanauske befolkning har sågar problemer med at placere ham inden for rammerne af selve menneskeheden. Hans 'overmenneskelige' karakter bliver endnu tydeligere, da han efter den opsigtsvækkende entre føres hen til den befalende guvernør:

64 Da jeg blev ført til guvernøren, spurgte han mig, hvor jeg kom fra. Jeg svarede, at det vidste jeg ikke. Så spurgte han: 'Hvor vil du da hen?' Jeg svarede igen: 'Det véd jeg ikke.' 'Hvad fanden véd du da?' spurgte han da, 'hvad er din håndtering?' Jeg svarede ligesom før, at det vidste jeg ikke. (I, 49)

Scenen fortsætter på samme vis gennem mange replikker endnu, og Simplicius' svar er altid det samme. Oprindeligt henviser ordet 'barbarisk' ikke kun til umenneske- 
lige eller irrationelt brutale fænomener, men også til de fremmede folkefærd som i antikkens verden ikke besad civilisationens sprog, dvs. græsk. I mødet med Hanaus guvernør optræder Simplicius som en skikkelse, der er langt fra at besidde stedets sprog (logos) og følgelig mangler evnerne til at optræde som et zoon politikon.

Perspektivet på Hanau-fæstningen som en polis i aristotelisk forstand er på trods af åbenlyse anakronismer en analytisk brugbar måde at tænke det tyske landskab under krigen på. Geopolitisk kan de tyske områder i begyndelsen af 1600-tallet beskrives som et ujævnt kludetæppe af større og mindre fyrstendømmer, kirkelige besiddelser og selvstændige købstæder. En stor del af den enorme kompleksitet, som omgiver Trediveårskrigen, skal findes i disse mange aktørers divergerende sympatier og interesseområder. I en tid før nationalstaten - og i mange tilfælde også før udbredelsen af en tidlig moderne stat - var det de lokale fyrster, hertuger og guvernører, som forestod magtudøvelsen i et distrikt, der for dele af lavadelens vedkommende i krigstid kunne begrænse sig til enkelte borge eller befæstede byer. Hanau er i Grimmelshausens roman at betragte som en isoleret, men selvtilstrækkelig bystat, hvor omgivelserne uden for fæstningen beherskes af lov- og partiløse lejesoldater, der plyndrer landevejene (ødelæggelsen af fædregården og de kidnappende kroater er gode eksempler).

Det er i forlængelse af denne adskillelse af ude og inde, af barbari og civilisation, at vi skal forstå Simplicius som et konkret fremmedlegeme, der i kraft af sin komplette andethed udfordrer Hanau-samfundets ontologi. Hvad der især bør kalde på opmærksomhed, er guvernørens reaktion på mødet. Med allusion til Apulejus' Det gyldne æsel forvandles Simplicius på guvernørens ordre til en nar i kalvekostume. Inspireret af Michel Foucaults afhandling om galskabens historie er det muligt at se denne manøvre som fornuftregimets forsøg på at inddæmme og udskille den ufornuftige Simplicius ved at umenneskeliggøre ham (Foucault 2003). I et krigssamfund, hvor de etablerede principper er under pres, vil den suveræne magt efterstræbe at understrege sin position ved at distancere sig selv fra de omvæltninger, som truer den traditionelle status quo, og som i romanen er indeholdt i heltens ankomst. Narren er en hyppigt fremkommende figur ved hoffet, der med sine flydende identiteter og generelle status som fremmed i verden kan imitere og parodiere alle de persontyper, livet måtte have at byde på. Den distancerede position gør det samtidig muligt for narren at afsløre virkelighedens tåbelige konventionaliteter (Bakhtin 2006, 81-87). Bakhtin-inspirerede læsninger af Simplicius' tid som nar er legio, ${ }^{\mathrm{I} 3}$ men det virker som om, at dybden af scenernes kritiske potentiale endnu ikke er blotlagt tilstrækkeligt. Karnevallet er den undtagelsestilstand, hvor narren spiller hovedrollen, og begivenheden er overordnet set kendetegnet ved en række omvendings- og udligningsfigurer, hvorigennem forskellen imellem de sociale lag udviskes i en kort periode for derefter at vende tilbage til normalen (Bakhtin 1984, 197). I Grimmelshausens bog ser vi dog den ikke uvigtige forskydning, at Trediveårskrigen ikke bare mimer en karnevalistisk tilstand, men yderligere truer med at gøre tilstanden permanent. Ved en af guvernørens banketter æder og drikker de tilstedeværende i en sådan grad, at Simplicius mistænker Kirke for at have forvandlet dem alle til svin. Scenen fremstilles i et tumultarisk sprog, som langt overskrider eksempelvis beskrivelsen af Wittstock-slaget, og romanen igennem bliver det tydeligt, 
at der næppe er forskel på de festende soldater ved taffelet og de kæmpende soldater på krigens slagmarker. Når undtagelsen er blevet hverdag og karnevallets indvarsling af forandring og opbrud den gældende diskurs, er guvernørens behov for at fremhæve sin væsensforskellighed fra Simplicius desto større. Planen giver dog delvist bagslag, eftersom vor helt - nu iført sin narredragt - på magisk vis har tilegnet sig sproget og straks angriber adelens fortrin: "Sig mig, hvilke herlige bedrifter der er øvet, og hvilke prisværdige kunster og ting der er opfundet, som er tilstrækkelige til at begrunde, at en hel slægt flere århundrede efter heltenes og kunstnernes død skal være adelige?” (II, 98-99). Og senere ved samme lejlighed:

46 Behold du derfor din commando og den løn, du vil få deraf; du behøver slet ikke dele noget deraf med mig; thi selv om alt går dig vel, ejer du til sidst ikke andet end en dårlig samvittighed. Men hvis du lyder din samvittighed, bliver du snart afsat fra dit embede som uduelig, ganske som om du havde været en dum kalv som jeg. (II, 104)

Episodens egentlige komik består her mindre i Simplicius' latterlige dyrekostume og mere i den desperate adels fors $\emptyset \mathrm{g}$ på at legitimere standsprivilegiernes universelle status. Hvad der startede som en konflikt mellem den rationelle civilisation og det irrationelle barbari, er nu blevet et spørgsmål om selv samme civilisations gyldighed internt i det hanauske fællesskab. Det herskende regimes grundlag skal dermed ikke udelukkende findes i modsætningsforholdet indenfor/udenfor, men også i de indre (op)delinger som overhovedet muliggør en social hierarkisering. Jacques Rancière kalder et sådant grundlag for en konsensus, og han beskriver den ulige fordeling af rettigheder og egenskaber inden for fællesskabet som en etisk lov, der knytter sig til en afgrænset lokation:

64 The law of the inside is doubled. Ethical in the first instance [as an abode] means that you interpret a sphere of experience as the sphere of the exercise of a property or a faculty possessed in common by all those who belong to a location. [...] As is well known, it soon is made apparent that this common property is not shared by everyone. (Rancière 2009, 3-4)

Retten til at tale om stand og politik er forbeholdt guvernøren og adelsmændene, men det er denne opdelte logos, Simplicius neutraliserer ved hjælp af sine nyvundne klæder og forstand. I Rancières terminologi er han en dissensus, som underminerer stedets konsensus. Guvernørens syn på narren er derfor præget af den største ambivalens, eftersom Simplicius i kraft af sin metafysiske karakter spiller en dobbelt rolle som opretholder og nedbryder af samfundets rationale.

Nogle afsluttende bemærkninger skal her lyde. Hovedpersonens evindelige forvandlinger og hans funktion som en typificeret og overfladisk karakter har gjort det muligt - om ikke andet så delvist - at kaste lys over romanens konstruktion af det relationelle forhold mellem identitet og rum. Med Hanau-eksemplet har hensigten været at vise, hvordan indflydelsen er gensidig. Helten transformeres til nar og tilegner sig en hidtil uset begavelse, men omvendt udfordres byens, og navnlig adelens, magtforhold af samme helts radikale andethed. Jeg 
anser det for tilladeligt at tolke denne andethed som et kondenseret udtryk for Trediveårskrigens konkrete tilstedeværelse i værket. På listen over metafysiske excesser ville man uden videre kunne tilføje fænomener som "begivenhed", "historie" og "krig", og det er følgelig værd at overveje Simplicius som en materiel personifikation af sådanne excesser. Hermed menes, at krigens abstrakte essens, dens indvarsling af opbrud og forandring, via Simplicius kropsliggøres og er til stede som en fysisk aktør i romanen. Det være sig i den forstand, at vi godtager krigens essens som en for menigmand uoverskuelig undtagelsestilstand, der, hvis den ikke ligefrem vendte samfundet på hovedet (som et andet karneval), i hvert fald forskød, forskubbede og forkludrede den gældende rangorden. Helten er ikke kun en symbolsk repræsentation af denne tilstand, men dens mærkbare udtryk i kød og blod.

Ovenstående har været et forsøg på at eftervise, hvordan Simplicius netop inkarnerer et væld af de mennesketyper, der udgjorde Trediveårskrigens sociale landskab. Men i stedet for blot at betragte helten som et skæringspunkt i krigens sociale og geografiske koordinatsystem, hvorigennem datidens samfund passivt spejles, skulle inddragelsen af den spekulative vinkel gerne illustrere, hvordan romanen operationaliserer en række historiske processer, som ligger hinsides dens rent denotative skildring af soldater og guvernører, fæstninger og slagmarker. Det er min påstand, at Grimmelshausens bog, på trods af det episodiske plots gæld til en traditionelt set tidsløs eventyrgenre, evner at give de enkelte scener en fornemmelse af tidslig foranderlighed i form af rummenes fortsatte ud- og afvikling. Hermed er Trediveårskrigen ikke et "tilfældigt sujet" eller en "teaterkulisse for et tidsløst theatrum mundi" som, men en ustabil størrelse i værket, som i udveksling med Simpliciuskarakteren genererer en dynamik, der, vil jeg mene, udtrykker et historisk potentiale. Romanen er en æstetisk iscenesættelse af et Europa i opbrud, hvor geografiske, sociale og subjektive grænsedragninger var til forhandling.

\section{Noter}

I Grimmelshausens værk omtales i dag almindeligvis som en roman, og da nærværende artikel ikke ønsker at beskæftige sig indgående med genrediskussioner vedrørende den tidlig moderne roman, vil den samme betegnelse også blive anvendt i det følgende.

2 For en filologisk fremstilling af forholdet mellem den historiske krig, Grimmelshausens biografi og Simplicissimus se Könnecke (1926-28).

3 Günter Grass i Werkausgabe in 10 bd., 1987, bd. 9, 922, her citeret efter Mannack (2002).

4 Dermed afviger artiklens udgangspunkt og mål betydeligt fra den kontekstualiserende læsning af romanens politisk-religiøse samtid, som Tatjana Kielland Samoilow for nylig har begået i Europæisk Litteratur 1500-1800. Staten (Samoilow 2015).

5 Det er værd at bemærke, at den eventyrlige indflydelse i tilfældet Simplicissimus stammer fra to traditioner. På den ene side den klassiske tradition startende med den græske og romerske roman og med den senere ridderroman som et afgørende overgangsstadie (jf. Bakhtin 2006). På den anden side folklore-traditionen, hvor legenderne om Till Uglenspiegel såvel som reminiscenser fra den tyske satiretradition, f.eks. Sebastian Brant (1457/58-1521), Thomas Murner 
(1475-1537) og Johann Michael Moscherosch (1601-1669), især er synlige.

6 Selv om kroaterne plyndrer videre undervejs formår de samme dag, som de ridder fra Hanau at komme til stiftet Hirschfeld (en rejse på knap 500 km) Kroaternes march sætter i nævnte eksempel spørgsmålstegn ved troværdigheden af kategorierne tid og rum.

7 I de senere værker i Grimmelshausens romancyklus har Simplicius forladt $\sin \emptyset$, og han optræder nu som bikarakter i historierne.

8 Fortælleren fremstår på overfladen muligvis som en streng forkynder af en kristen doktrin, men den rene fortællelyst kommer somme tider over ham på en sådan måde, at der snarere er tale om underholdning end opbyggelighed: "Jeg må nu fortælle lidt om, hvad jeg oplevede, før jeg atter skiltes fra mine dragoner, og selv om det ikke er vigtige ting, er de dog fornøjelige at høre." (II, 152). John Heckman har sågar foreslået, at fortælleren skulle have mere til fælles med djævlen end f.eks. Augustin og Skt. Antonius (Heckman 1969).

9 Bag de fælles tendenser, som falder under den historiske narratologi, ligger et opgør med den strukturalistiske traditions intratekstuelle og synkrone blik på fortællepositionerne, men der tages samtidig afstand fra kontekstualiserende skoler som f.eks. nyhistorismen og kulturelle erindringsstudier (Werner 2018, 38ff). En længere redegørelse skal ikke foreligge her og bevægelsen blot nævnes, fordi Werner som en af dens fremmeste repræsentanter har nogle fine pointer i sin analyse af den fortælletekniske fremstilling af tid. For det teoretiske grundlag bag den historiske narratologi se f.eks. antologien Neue Ansätze in der Erzähltheorie, red.: Ansgar/Vera Nünning (2002); Monika Fludernik: "The Diachronization of Narratology" (2003); Lukas Werner: "Elemente einer historischen Narratologie" (2012).

Io "Den folgenden Ausführungen liegt die Überzeugung zugrunde, dass sich eine Historisierung von Zeit nicht in der Einbettung eines Erzähltextes in soziohistorische, diskursive oder andere nicht-literarische Kontexte erschöpfen muss, sondern dass ein relationaler Begriff von Zeit eine Historisierung möglich macht, in der die kompositorische und literarische Gemachtheit des Textes im Vordergrund steht."

II "Das Mitteleuropa des 30jährigen Krieges ist kein zufälliges Sujet für eine in Genre verkleidete Allegorie. Es bildet vielmehr die Welt, die sich der Held anzueignen hat, und gehört damit zur Substanz des Romans. Der räumliche und zeitliche Rahmen der Handlung ist keine Theaterkulisse für ein zeitloses theatrum mundi, sondern das objektive Handlungsfeld, in dem sich die Subjektivität des Helden, seine unverwechselbare Biographie, überhaupt erst konstituiert. Umgekehrt kommt diese objektive Welt erst durch die Bewegung des Helden in den Blick."

I2 I de scener, hvor Simplicius huserer som jægeren fra Soest, har han en direkte adfærdsregulerende funktion, idet man på både svensk og kejserlig side skifter strategier og finder på nye måder at begå sig i området omkring Soest på. (f.eks. III, 21-24 \& III, 29-32).

I3 Anne Leblans har dog påvist de implikationer, der følger af en for direkte overførsel af Bakhtins karnevalisme-begreb fra Rabelais til Grimmelshausen (Leblans 1990).

\section{Litteratur}

Alewyn, Richard (1932): Johann Beer. Studien zum Roman des siebzehnten Jahrhunderts, Leipzig: Palaestra.

Aristoteles (2012): Politics, Newburyport: Dover Publications.

Aylett, Robert (1982): The Nature of Realism in Grimmelshausen's Simplicissimus Cycle of Novels, 
Bern: Peter Lang Publishers.

Bakhtin, Mikhail M. (1984): Rabelais and his world, Bloomington: Indiana University Press.

Bakhtin, Mikhail M. (2006): Rum, Tid \& Historie - Kronotopens former i europæisk litteratur, Aarhus: Forlaget Klim.

Butler, Judith (2001): "Giving an Account of Oneself", i Diacritics 31, s. 22-40.

Cordie, Ansgar (2001): Raum und Zeit des Vaganten. Formen der Weltaneignung im deutschen Schelmenroman des 17. Jahrhunderts, Berlin/New York: De Gruyter.

Foucault, Michel (2003): Galskabens historie i den klassiske periode, København: DET lille FORLAG.

Grimmelshausen, Hans Jakob Christoffel von (1963): Den eventyrlige Simplicissimus, København: Hans Reitzel Serie.

Harbsmeier, Michael (2012): “Fra Trediveårskrigen til Sturm und Drang 1648-1789”, i Detlef Siegfried og Anna Sandberg (red.): Tysk Kulturhistorie, København: Gyldendal, s. 19-47.

Heckman, John (1969): “Emblematic Structures in Simplicissimus Teutsch” i MLN 84, s. 876-890.

Konopatzki, Ilse-Lore (1965): “Grimmelshausens Legendenvorlagen”, i Philologische Studien und Quellen 28.

Könnecke, Gustav (1926-28): Quellen und Forschungen zur Lebensgeschichte Grimmelshausens, Weimar \& Leipzig: Herausgegeben im Auftrag der Gesellschaft der Bibliophilen von J. H. Scholte.

Leblans, Anne (1990): "Grimmelshausen and the Carnivalesque: The Polarization of Courtly and Popular Carnival in Der abenteuerliche Simplicissimus", i MLN 105, s. 494-511.

Nancy, Jean-Luc (2009): "Rancière and Metaphysics", i G. Rockhill og P. Watts (red.): Jacques Rancière. History, Politics, Aesthetics, London: Duke University Press, s. 83-92.

Mannack, Eberhard (2002): "Der Streit der Historiker und Literaten über den Dreißigjährigen Krieg und Westfälischen Frieden" i Daphnis 31, s. 701-712.

Maroszová, Jana (2015): “Zeit im Kontext. Rhetorik, Allegorie und erzählte Zeit in Grimmelshausens simplicianischen Schriften”, i Antonius Waixler og Lukas Werner (red.): Zeiten erzählen, Ansätze - Aspekte - Analysen, Berlin \& Boston: De Gruyter, s. 105-126.

Meid, Volker (1974): Der deutsche Barockroman, Stuttgart: J. B. Metzlersche Verlagsbuchhandlung. Meid, Volker (1984): Grimmelshausen. Epoche - Werk - Wirkung, München: Beck.

Mohr, Jan (2011): "Inseln und Inselräume. Kontingenz in Grimmelshausens und Dürers Schelmenromanen", i Patrick Ramponi et al. (red.): Inseln und Archipele, Kulturelle Figuren des Insularen zwischen Isolation und Entgrenzung, Bielefeld: Transcipt Verlag, s. 225-244.

Propp, Vladimir (1973): Morphology of the Folktale, Austin \& London: University of Texas Press.

Rancière, Jacques (2009): “The Aesthetic Dimension: Aesthetics, Politics, Knowledge”, i Critical Inquiry 36, s. 1-19.

Samoilow, Tatjana Kielland (2015): "Krigens nullpunkt. Dyd, utopi og drømmen om politisk orden i Grimmelshausens Simplicissimus", i Knut Ove Eliassen et al. (red.): Europæisk Litteratur 1500-1800. Staten. Fra utopi til bureaukrati, Aarhus: Aarhus Universitetsforlag, s. 135-159.

Stanzel, Franz K. (1972): Typische Formen des Romans, Göttingen: Vandenhoeck \& Ruprecht. Werner, Lukas (2015): “Zeit im Text - Möglichkeiten der formalen Historisierung. Zur Relation von Zeit und Ich-Erzähler in Grimmelshausens Simplicissimus und Schnabels Insel Felsenburg”, i Antonius Waixler og Lukas Werner (red.): Zeiten erzählen, Ansätze-Aspekte-Analysen, Berlin \& Boston: De Gruyter, s. 79-104.

Werner, Lukas (2018): Erzählte Zeiten im Roman der Frühen Neuzeit. Eine historische Narratologie der Zeit, Berlin \& Boston: De Gruyter. 
